JKEP

Vol 6, No 1 (2021)

ISSN: 2354-6042 (Print)

ISSN : 2354-6050 (Online)

\title{
Gambaran Stres Psikososial dan Faktor-Faktor yang Mempengaruhinya Pada Remaja
}

\author{
Nurul Intan Rendra Zola ${ }^{1}$, Fathra Annis Nauli ${ }^{2}$, Gamya Tri Utami ${ }^{3}$ \\ Fakultas Keperawatan Universitas Riau \\ Email: nurulintanrz@gmail.com
}

\author{
Artikel history \\ Dikirim, Aug 24 ${ }^{\text {th }}, 2019$ \\ Ditinjau, April 19 ${ }^{\text {th }}, 2021$ \\ Diterima, Mei $30^{\text {th }}, 2021$
}

\begin{abstract}
ABSTRACK
Teenagers are a transition from children to adults who have a lot of changes, it causes teens to experience psychological stress. The factors that influence psychosocial stress are living conditions, school environment, family economic status, relationships with others, unplanned events and habits. This study aim to determine the description of psychosocial stress and the factors that influence it in students at SMAN 8 Pekanbaru. The total respondents were 101 respondents using accidental sampling.. The measuring instrument used was a questionnaire from Holmes and Rahe and analyzed using univariate.. The results showed that the majority of respondents experienced moderate psychosocial stress (47.5\%). Respondents who experienced the condition of the living environment factors were $51.5 \%$, the state of the school environmental factors were $50.5 \%$, family economic status factors were $37.6 \%$, relationship factors with other people were $49.5 \%$, unplanned incidence factors were as many as 31,7\% and habit 2,\% showed psychosocial stress. The researcher concluded that the majority of respondents experienced moderate psychosocial stress with the most influencing factor is the state of the environment in which they live. This research recommends adolescents to add information and add insight about psychosocial stress and the factors that influence it and can prevent it.
\end{abstract}

Keywords: psychosocial stress, psychosoial stress factors, adolescents

\begin{abstract}
ABSTRAK
Remaja merupakan masa peralihan dari anak-anak menjadi dewasa yang banyak mengalami perubahan, sehingga mengakibatkan remaja mengalami stres psikososial. Faktor yang mempengaruhi stres psikososial adalah keadaan tempat tinggal, keadaan lingkungan sekolah, status ekonomi keluarga, hubungan dengan orang lain, kejadian tidak direncanakan dan kebiasaan. Penelitian ini bertujuan untuk mengetahui gambaran stres psikososial dan faktor-faktor yang mempengaruhinya pada remaja di SMAN 8 Pekanbaru. Metode yang dilakukan peneliti adalah kuantitatif dengan desain penelitian deskriptif. Sampel yang digunakan dalam penelitian ini sebanyak 101 responden yang diambil dengan teknik accidental sampling. Alat ukur yang digunakan adalah kuesioner
\end{abstract}


dari Holmes dan Rahe dengan analisa datanya adalah analisa univariat. Hasil penelitian menunjukkan bahwa sebagian besar responden mengalami stres psikososial sedang $(47,5 \%)$. Responden yang mengalami faktor keadaan lingkungan tempat tinggal sebanyak $51,5 \%$, faktor keadaan lingkungan sekolah sebanyak 50,5\%, faktor status ekonomi keluarga sebanyak 37,6\%, faktor hubungan dengan orang lain sebanyak 49,5\%, faktor kejadian tidak direncanakan sebanyak 31,7\% dan kebiasaan sebanyak 2,\% menunjukkan stres psikososial. Peneliti menyimpulkan bahwa mayoritas responden mengalami stres psikososial sedang dengan faktor yang paling mempengaruhinya adalah keadaan lingkungan tempat tinggal. Penelitian ini merekomendasikan kepada guru, orangtua maupun pendamping remaja lainnya untuk meningkatkan wawasan siswa tentang stres psikososial dan cara mencegahnya.

Kata kunci: stres psikososial, faktor stress psikososial, remaja

\section{PENDAHULUAN}

Ali dan Asrori (2018) menyatakan bahwa masa remaja adalah masa transisi yang sangat kompleks. Remaja ketika menuju dewasa mengalami berbagai perubahan yang ditandai dengan perubahan fisik. Selain itu, remaja juga mengalami perubahan perkembangan kognitif dan perkembangan psikososial. Potter dan Perry (2010) menyatakan perkembangan psikososial adalah salah satu aspek penting dalam terjadinya perubahan dalam diri remaja.

Salah satu faktor yang berperan penting dalam mencari identitas diri seseorang adalah perkembangan psikososial merupakan karena penilaian dari orang lain tentang dirinya sebagai suatu kesatuan yang utuh meliputi peran, tujuan pribadi dan ciri khas (Fajariyah, 2012). Remaja yang tidak bisa mengatasi perubahan-perubahan yang terjadi, maka akan terjadi krisis identitas. Terjadinya krisis identitas disebabkan karena remaja merasa dirinya sudah dewasa, sehingga remaja seringkali kebingungan peran terhadap identitas dirinya. Selain itu, krisis identitas yang dialami oleh remaja dikarenakan pola asuh orang tua, terpengaruh oleh lingkungan, teman sebaya, pengalaman hidup, dan salah paham antar remaja (Sumiati \& Lailan, 2012). Remaja yang mengalami krisis identitas akan menyebabkan banyak terjadinya masalah, seperti adanya pengaruh dan tindak kekerasan, buruknya tata bahasa, perilaku merusak diri yang meningkat, serta rasa hormat pada orang tua dan guru yang menurun. Masalah-masalah tersebut jika tidak diatasi maka akan menyebabkan stres (Purwanti, 2013).

Stres menurut Nasir dan Muhith (2011) merupakan respon atau reaksi dari tubuh terhadap lingkungan yang dapat memproteksi diri, serta stres merupakan 
termasuk salah satu sistem pertahanan yang membuat individu tetap hidup. Nadeak, Tienne dan Albiner (2013) mengatakan stres pada remaja dapat disebabkan oleh orangtua yang menuntut anaknya untuk mempunyai nilai bagus di sekolah tanpa melihat kemampuan anak. Respon stres yang dialami oleh remaja cenderung berlebihan daripada orang dewasa karena adanya proses maturitas bagian otak pada remaja. Salah satu stres yang remaja alami yaitu stres psikososial.

Cahyani (2016) mengatakan stres psikososial disebabkan oleh interaksi dengan individu lain yang ada disekelilingnya dan kondisi sosial lainnya, seperti kejadian hidup yang membuat remaja tertekan dan menimbulkan stres akut terhadap individu. Putri (2014) mengatakan faktor yang mempengaruhi stres psikososial pada remaja disebabkan oleh beberapa masalah, contohnya permasalahan terkait keluarga, teman sebaya, kematian seseorang, memiliki penyakit dan lainlain. Ketika remaja mengalami stres psikososial yang berkelanjutan dan tidak diatasi, maka akan meningkatkan resiko remaja tersebut menjadi depresi saat dewasa.
Putri (2014) mengatakan remaja yang sering mengalami kejadian yang tidak menyenangkan didalam hidupnya akan lebih beresiko menjadi depresi dibandingkan dengan remaja yang mengalami kejadian tidak menyenangkan satu kali. Remaja yang mengalami depresi akan mengatakan bahwa diri mereka bodoh, tidak menarik, tidak mampu menjalin hubungan pertemanan dan dengan lawan jenis, serta merasa tidak disukai oleh orang lain. Thapar et al., (2012) mengatakan bahwa faktor yang mempengaruhi remaja yang mengalami stres psikososial dan menyebabkan depresi yang tertinggi adalah kejadian tak terencana atau tak terkira seperti kematian orang tua pacar dan teman dekat.

Hasil penelitian Putri (2014) menyatakan remaja yang mengalami stres psikososial berat sebesar $(11,3 \%)$, stres psikososial sedang sebesar $(36,9 \%)$ dan stres psikososial ringan sebesar (36,9\%). Faktor yang paling mempengaruhi stres psikososial yaitu faktor kebiasaan sebanyak (46,1\%). Azizah et al., (2018) meneliti tentang faktor-faktor yang berhubugan dengan masalah psikososial remaja di wilayah Bantaran Kali Code Kota Yogyakarta 
mendapatkan bahwa $11,6 \%$ remaja mengalami masalah psikososial dan faktor yang menyebabkannya adalah tingkat pendidikan, dukungan orangtua dan kelayakan tempat tinggal.

Studi pendahuluan yang dilakukan peneliti pada tanggal 14 Januari 2020 dengan menggunakan kuesioner Skala Holmes dan Rahe Non-Adult di SMAN 8 Pekanbaru pada 33 responden menunjukkan siswa yang mengalami stres psikososial berat $(81,82 \%)$ dipengaruhi oleh keadaan lingkungan tempat tinggal $(44,44 \%)$, stres psikososial sedang $(15,15 \%)$ dipengaruhi oleh keadaan lingkungan sekolah (60\%) dan stres psikososial ringan $(3,03 \%)$ dipengaruhi oleh hubungan dengan orang lain. Hasil wawancara dengan beberapa siswa di SMAN 8 Pekanbaru yang terkena sistem zonasi mengatakan bahwa mereka tidak ingin masuk ke sekolah tersebut karena siswa-siswa di SMAN 8 Pekanbaru dikenal dengan siswa yang berprestasi dan pintar. Mereka menjadi tidak percaya diri untuk bersekolah di SMAN 8 Pekanbaru karena mereka tahu bagaimana kemampuannya. Mereka menjadi semakin malas belajar dan tidak peduli dengan lingkungannya. Berdasarkan penelitian tersebut, selanjutnya peneliti ingin mengetahui faktor-faktor yang mempengaruhi terjadinya stress psikososial pada remaja di SMAN 8 Pekanbaru.

\section{METODE PENELITIAN}

Peneliti mengunakan desain penelitian deskripstif. Pada penelitian ini, peneliti ingin mengetahui gambaran stres psikososial dan faktor-faktor yang mempengaruhinya pada remaja di SMAN 8 Pekanbaru.

\section{HASIL}

Tabel 1 menunjukkan karakteristik berdasarkan jenis kelamin responden terbanyak yaitu perempuan dengan jumlah 63 responden $(62,4 \%)$, berdasarkan umur responden terbanyak yaitu berumur 16 tahun dengan jumlah 48 responden $(47,5 \%)$, berdasarkan kelas dan jurusan responden terbanyak yaitu kelas XI IPA dengan jumlah 39 responden $(38,5 \%)$. 
Tabel 1. Distribusi Frekuensi Karakteristik Responden

\begin{tabular}{lcc}
\hline \multicolumn{1}{c}{ Karakteristik Responden } & Jumlah $(\mathrm{n})$ & Presentase $(\%)$ \\
\hline Jenis Kelamin & & \\
Laki-Laki & 38 & 37,6 \\
Perempuan & 63 & 62,4 \\
\hline Umur & & \\
15 tahun & 29 & 28,7 \\
16 tahun & 48 & 47,5 \\
17 tahun & 23 & 22,8 \\
18 tahun & 1 & 1,0 \\
\hline Kelas dan Jurusan & & \\
X IPA & 29 & 28,7 \\
X IPS & 19 & 18,8 \\
XI IPA & 39 & 38,5 \\
XI IPS & 14 & 13,9 \\
\hline Total & 101 & 100 \\
\hline
\end{tabular}

Penelitian yang dilakukan di SMAN 8 Pekanbaru menunjukkan bahwa berdasarkan karakteristik jenis kelamin, mayoritas responden adalah perempuan dengan jumlah 63 responden $(62,4 \%)$. Hal ini sejalan dengan hasil penelitian Putri (2014) tentang prevalensi stres psikososial menunjukkan bahwa mayoritas responden berjenis kelamin perempuan $(56 \%)$ dengan mengalami stres psikososial ringan sebesar 33,3\% dan laki-laki (44\%) dengan stres psikososial ringan $18,4 \%$. Azizah et al., (2018) mengatakan anak perempuan lebih cenderung mengalami masalah psikososial daripada anak laki-laki. Hal tersebut dikarenakan adanya pengaruh pada faktor pubertas pada anak perempuan dan laki-laki.
Hasil penelitian yang dilakukan di SMAN 8 Pekanbaru menunjukkan bahwa karakteristik berdasarkan umur responden terbanyak yaitu berumur 16 tahun dengan jumlah 48 responden (47,5\%). Berdasarkan Peraturan Menteri Pendidikan dan Kebudayaan (Permendikbud) Nomor 44 tahun 2019 pasal 5 ayat 1(a) mengenai persyaratan calon peserta didik baru kelas 1 (satu) SD berusia 7 (tujuh) tahun sampai dengan 12 (dua belas) tahun, sehingga calon peserta didik baru kelas $\mathrm{X}$ mayoritas berumur 15 tahun dan kelas XI berumur 16 tahun yang termasuk remaja pertengahan.

Hasil penelitian Putri (2014) mengenai prevalensi stres psikososial pada siswasiswi kelas XII studi pendidikan IPA dan 
IPS SMAN 6 Denpasar menunjukkan bahwa prevalensi stres psikososial terbanyak yaitu pada umur 17 tahun, hal ini dikarenakan mayoritas responden berada pada usia tersebut. Diananda (2018) mengatakan ketika remaja mencari identitas, remaja merasa bisa untuk membuat keputusan sendiri dikarenakan pola hubungan sosial mulai berubah dan menganggap diri sebagai orang dewasa muda.

Hasil penelitian yang dilakukan di SMAN 8 Pekanbaru menunjukkan bahwa karakteristik berdasarkan kelas responden terbanyak yaitu kelas XI IPA dengan jumlah 39 responden $(38,5 \%)$. Hal ini sesuai dengan penelitian Jauhari (2019) mengenai tingkat stres yang dialami oleh siswa menunjukkan bahwa siswa dengan jurusan IPA mengalami stres $(97,1 \%)$. Hasil penelitian yang dilakukan oleh Muhajirin (2016) di SMA 3 Islam Sultan Agung Semarang menunjukkan bahwa siswa jurusan IPA
$(41,30 \%)$ memiliki tingkat stres yang lebih tinggi daripada siswa jurusan IPS (21,74\%), sehingga peneliti menyimpulkan bahwa siswa dengan jurusan IPA lebih sering mengalami stres daripada siswa dengan jurusan IPS.

Tabel 2 menunjukkan gambaran stres psikososial pada remaja, stres psikososial terbanyak yaitu stres sedang sebanyak 48 responden (47,5\%). Tabel 3 menunjukkan bahwa dari 101 responden, faktor keadaan lingkungan tempat tinggal mempengaruhi sebanyak $51,5 \%$ responden, faktor keadaan lingkungan sekolah mempengaruhi sebanyak 50,5\% responden, faktor status ekonomi keluarga mempengaruhi sebanyak $37,6 \%$ responden, faktor hubungan dengan orang lain mempengaruhi sebanyak $\quad 49,5 \%$ responden, faktor kejadian tidak direncanakan mempengaruhi sebanyak $31,7 \%$ responden dan faktor kebiasaan mempengaruhi sebanyak $2 \%$ responden.

Tabel 2. Distribusi Frekuensi Responden Berdasarkan Kejadian Stres Psikososial

\begin{tabular}{llcc}
\hline No & \multicolumn{1}{c}{ Stres Psikososial } & Jumlah $(\mathrm{n})$ & Presentase $(\%)$ \\
\hline 1. & Stres ringan & 17 & 16,8 \\
\hline 2. & Stres sedang & 48 & 47,5 \\
\hline 3. & Stres berat & 36 & 35,6 \\
\hline & Total & 101 & 100 \\
\hline
\end{tabular}


Putri (2014) menyatakan bahwa remaja yang mengalami stres sedang menunjukkan $50 \%$ kemungkinan penyakit karena faktor stres. Santrock (2011) mengatakan pada masa ini remaja pertama kalinya mendapat banyak masalah. Biasanya permasalahan yang remaja alami seperti persoalan berat badan, jerawat, menstruasi, tertinggalnya perkembangan, rangsangan seksual, stres tentang sekolah, mudah bosan, orang tua yang cerewet, teman sebaya yang memberi tekanan, dan masalah uang. Masala tersebut akan mengakibatkan remaja sangat berisiko mengalami stres.

Tabel 3. Distribusi Frekuensi Responden Berdasarkam Faktor-Faktor yang Mempengaruhi Stres Psikososial pada Remaja

\begin{tabular}{|c|c|c|c|c|c|c|c|}
\hline \multirow{3}{*}{ No. } & \multirow{3}{*}{$\begin{array}{c}\text { Faktor-Faktor yang } \\
\text { Mempengaruhi }\end{array}$} & \multicolumn{4}{|c|}{ Jumlah (n) } & \multirow{2}{*}{\multicolumn{2}{|c|}{ Total }} \\
\hline & & \multicolumn{2}{|c|}{$\mathrm{Ya}$} & \multicolumn{2}{|c|}{ Tidak } & & \\
\hline & & $\mathrm{n}$ & $\%$ & $\mathrm{n}$ & $\%$ & $\mathrm{~N}$ & $\%$ \\
\hline 1. & $\begin{array}{l}\text { Keadaan Lingkungan Tempat } \\
\text { Tinggal }\end{array}$ & 52 & 51,5 & 49 & 48,5 & 101 & 100 \\
\hline 2. & Keadaan Lingkungan Sekolah & 51 & 50,5 & 50 & 49,5 & 101 & 100 \\
\hline 3. & Status Ekonomi Keluarga & 38 & 37,6 & 63 & 62,4 & 101 & 100 \\
\hline 4. & Hubungan dengan Orang Lain & 50 & 49,5 & 51 & 50,5 & 101 & 100 \\
\hline 5. & Kejadian Tidak Direncanakan & 32 & 31,7 & 69 & 68,3 & 101 & 100 \\
\hline 6. & Kebiasaan & 2 & 2,0 & 99 & 98,0 & 101 & 100 \\
\hline
\end{tabular}

Hasil penelitian yang dilakukan di SMAN 8 Pekanbaru menunjukkan bahwa terdapat beberapa faktor-faktor yang mempengaruhi stres psikososial pada remaja, yaitu keadaan lingkungan tempat tinggal, keadaan lingkungan sekolah, status ekonomi keluarga, hubungan dengan orang lain, kejadian tidak direncanakan dan kebiasaan.

Keadaan lingkungan tempat tinggal adalah salah satu faktor yang mempengaruhi stres psikososial pada remaja sebanyak 51,5\%. Hal tersebut dikarenakan pada saat pandemi Covid19 diharuskan para orang tua untuk bekerja di rumah dan kurang harmonisnya hubungan antar orang tua yang membuat remaja menjadi stres. Hal ini sejalan dengan penelitian yang dilakukan oleh Putri (2014) remaja menjadi lebih stres disebabkan oleh adanya ketidakharmonisan hubungan orang tua yang terjadi dalam jangka waktu lama. Evanda (2015) mengatakan salah satu yang mempengaruhi stres 
pada seseorang dan kemampuannya dalam beradaptasi adalah lingkungan. Lingkungan sangat mempengaruhi tingkat stres seseorang dan biasanya permasalahan muncul dari lingkungan fisik dan sosial.

Keadaan lingkungan sekolah adalah salah satu faktor yang mempengaruhi stres psikososial pada remaja sebanyak 50,5\%. Mayoritas responden dalam penelitian ini sudah menjadi senior karena responden kebanyakan kelas XI dan memiliki prestasi yang membanggakan. Hal ini sejalan dengan penelitian Nadeak, Tienne \& Albiner (2013) mengatakan stres pada remaja dapat disebabkan oleh orangtua yang menuntut anaknya untuk mempunyai nilai bagus di sekolah tanpa melihat kemampuan anak. Hasil penelitian Putri (2014) mengatakan remaja cenderung mendapat bully dari sesama teman di sekolah. Hurlock (2011) mengatakan alasan remaja sering mengalami masalah yang sulit diatasi yaitu mereka merasa mandiri, ingin menyelesaikan masalahnya sendiri dan menolak bantuan orang lain terutama orang tua dan guru-guru. Alasan-alasan tersebut memungkinkan siswa SMA mengalami kecemasan. ekstrakurikuler dan kegiatan positif lainnya.

Status ekonomi keluarga adalah salah satu faktor yang mempengaruhi stres psikososial pada remaja sebanyak 37,6\%. Hal ini dikarenakan beberapa responden mengalami efek dari pandemi yang mengakibatkan para orang tua kehilangan pekerjaan dan tidak adanya pemasukan tambahan. Hal ini sejalan dengan penelitian Azizah et al., (2018) yang menunjukkan bahwa status sosial ekonomi dilihat dari pekerjaan orang tua responden memiliki hubungan yang bermakna dengan masalah psikososial remaja di wilayah bantaran Kali Code Kota Yogyakarta. Putri (2014) mengatakan remaja banyak mengalami stres bisa disebabkan oleh status ekonomi yang berada pada level bawah

Hubungan dengan orang lain adalah salah satu faktor yang mempengaruhi stres psikososial pada remaja sebanyak 49,5\%. Hal ini dikarenakan remaja butuh teman untuk menjadi tempat curahan hatinya dan dikarenakan saat ini sedang dalam masa pandemi Covid-19, remaja juga mengalami perubahan tingkah laku oleh teman sebaya. Putri (2014) mengatakan ketika remaja mengalami 
masalah, remaja tersebut akan mencari seseorang yang akan menjadi tempat curahan hatinya. Remaja akan mengalami stres jika hubungan dengan orang lain tidak baik. Sumara, Humaedi dan Santoso (2017) mengatakan kenakalan remaja bisa mengakibatkan remaja melakukan tindakan yang menyimpang. Dampak bagi keluarga pada remaja yang berkelakuan menyimpang yaitu putusnya komunikasi antara orang tua dan anak. Remaja memiliki kebutuhan yang kuat untuk disukai dan diterima teman sebaya atau kelompok, seperti tidak suka jika ditolak dan sebaliknya akan merasa senang dan bahagia apabila diterima oleh temanteman sebayanya.

Kejadian tidak direncanakan adalah salah satu faktor yang mempengaruhi stres psikososial pada remaja sebanyak $31,7 \%$. Hal ini dikarenakan remaja mengalami kejadian yang ia tidak inginkan dan rencanakan, sehingga membuat remaja menjadi stres. Putri (2014) mengatakan kejadian tidak direncanakan yang dialami remaja, seperti orang tua yang meninggal, pacar dan teman dekat yang meninggal juga membuat remaja menjadi stres.
Kebiasaan adalah salah satu faktor yang mempengaruhi stres psikososial pada remaja sebanyak 2\%. Hal ini dikarenakan remaja bersekolah di salah satu sekolah favorit dan memikirkan dampak kedepannya. Remaja mempunyai kebiasaan dalam menghadapi masalah dengan emosional dan cenderung menghindar. Remaja yang banyak mengalami permasalahan akan berperilaku, seperti agresifitas, membolos, mabuk, narkoba, serta pergaulan bebas (Ahyani \& Astuti, 2018).

\section{SIMPULAN}

Rata-rata responden penelitian berumur 16 tahun dengan rentang 14-18 tahun dengan jenis kelamin perempuan. Mayoritas responden mengalami stres psikososial sedang (47,5\%). Responden yang mengalami faktor keadaan lingkungan tempat tinggal sebanyak $51,5 \%$, faktor keadaan lingkungan sekolah sebanyak 50,5\%, faktor status ekonomi keluarga sebanyak 37,6\%, faktor hubungan dengan orang lain sebanyak 49,5\%, faktor kejadian tidak direncanakan sebanyak $31,7 \%$ dan kebiasaan sebanyak 2,\% menunjukkan stres psikososial. 


\section{SARAN}

1. Bagi Keperawatan

Sebagai bahan referensi bagi instansi keperawatan yang terkait dalam memberikan edukasi atau fenomena stres psikososial dan faktor-faktor yang mempengaruhinya pada remaja.

2. Bagi Masyarakat Pendidikan

Guru/pendidik dapat memfasilitasi informasi tentang stres psikososial dan faktor-faktor yang mempengaruhinya pada remaja dan bagaimana cara pencegahannya

3. Bagi Peneliti Selanjutnya

Penelitian ini dapat dipakai sebagai bahan pertimbangan dan mengembangkan kuesioner penelitian tentang penatalaksanaan stress pada remaja

\section{DAFTAR RUJUKAN}

Ahyani, Latifah Nur, \& Astuti, Dwi. 2018. Psikologi Perkembangan Anak dan Remaja. Kudus: Badan Penerbit Universitas Muria Kudus.

Ali, M., \& Asrori, M. 2018. Psikologi Remaja Perkembangan Peserta Didik. Jakarta: PT Bumi Aksara.
Azizah, U., Haryan, F., \& Wahyuni, B. 2018. Faktor-Faktor yang Berhubungan dengan Masalah Psikososial Remaja Di Wilayah Bantaran Kali Code Kota Yogyakarta. BKM Journal of Community Medicine and Public Health, 34(7), 281-290.

Cahyani, I. R. 2016. Hubungan Antara Status Stress Psikososial dengan Konsumsi Makanan dan Status Gizi Remaja di SMA Negeri 2 Jember.

Diananda, A. 2018. No Title. Istighna, 1(1), 116-133. http://e-journal.stitislamic-village.ac.id

Dharma, K. K. 2015. Metotologi Penelitian Keperawatan (Pedoman Pelaksanaan Dan Menerapkan Hasil Penelitian). Jakarta: Trans Info Media.

Evanda, R. bagus. 2015. Faktor-Faktor Internal Yang Mempengaruhi Stres Pada mahasiswa Angkatan 2014 Fakultas Kedokteran Universitas Jember. Skripsi, 43.

Fajariyah, N. 2012. Asuhan Keperawatan dengan Gangguan Harga Diri Rendah. Jakarta: CV. Trans Info Media.

Hidayat, A. A. 2012. Riset Keperawatan dan Teknik Penulisan Ilmiah, Edisi 2. Jakarta: Salemba Medika.

Jauhari, P. M. 2019. Analisis Tingkat Stres Akademik Siswa IPA dan Siswa IPS di SMA Ungukan SeKota Palembang Tahun 2019. Skripsi, 8(5), 55. 
Kemendikbud. 2019. Peraturan Menteri Pendidikan dan Kebudayaan Nomor 44 tahun 2019.

Muhajirin. 2016. Perbedaan Tingkat Stres pada Remaja Siswa Kelas Xi Jurusan Ilmu Pengetahuan Alam (IPA) dengan Remaja Siswa Jurusan Ilmu Pengetahuan Sosial (Ips) Di SMA 3 Islam Sultan Agung Semaraang. Skipsi.

Nadeak, Tienne, A., \& Albiner, S. 2013. Hubungan Status Stres Psikososial dengan Konsumsi Makanan dan Status Gizi Siswa SMUA Methodist8 Medan. Desember, 1-8.

Potter, P, A., \& Perry, A, G. 2010. Fundamental Keperawatan, Edisi 7. Jakarta: Salemba Medika.

Purwanti, F. 2013. Identitas Diri Remaja Pada Siswa Kelas Xi SMA Negeri 2 Pemalang Ditinjau dari Jenis Kelamin. Journal Psychology Universitas Negeri Semarang, 1(1), 21-27.

https://doi.org/10.1017/S13689800 07000298

Sumara, D. S., Humaedi, S., \& Santoso, M. B. 2017. Kenakalan Remaja dan Penanganannya. Prosiding Penelitian dan Pengabdian kepada Masyarakat, 4(2).
Putri, Wayan Diah Anima Winayaka. 2014. The Prevalence of Psychosocial Stress and Affecting Factors among The Students Xii Grade Science and Social Education at SMAN 6 Denpasar. Stres Psikososial, 3.

Santrock, John W. 2011. Perkembangan Anak Edisi 7 Jilid 2. Jakarta: Erlangga

Sumiati, E., \& Lailan, M. 2012. Pengetahuan dan Sikap Remaja Tentang Identitas Diri Remaja pada Siswa Sma Kartika I-2 Medan. Jurnal Keperawatan Holistik, 1(1), 30-34.

Thapar, A., Collishaw, S., Pine, D. S., \& Thapar, A. K. 2012. Depression in adolescence. The Lancet, 379(9820), 1056-1067. https://doi.org/10.1016/S01406736(11)60871-4

Yendork, J., \& Somhlaba, N. Z. 2014. Stress, Coping and Quality of Life: An Exploratory Study of The Psychological Well-Being of Ghanaian Orphans Placed In Orphanages. Children and Youth Services Review, 46, 28-37. https://doi.org/10.1016/j.childyout h.2014.07.025 